\title{
Effect of Some Chemicals on Vase Life of Gladiolus Cut Flowers
}

\author{
Mahmoud Khattab1, Mohammed El-Torky ${ }^{1}$, Abd-El-Hamid Torabeih ${ }^{2}$, Hend Rashed ${ }^{1}$
}

\begin{abstract}
The present study was carried out during two seasons of 2015/2016 under laboratory conditions in the Department of Floriculture, Ornamental Horticulture and Garden Design Faculty of Agriculture, University of Alexandria at Shatby and Behira Governorate (Abo ElMatameer city) to investigate the possibility of opening the florets of the cut spikes of Gladiolus grandiflorus cv."White Prosperity" at show color stage, inflorescence keeping quality, leaves chemical analysis and the growth of microorganisms in the vase solution using three concentrations of each of ascorbic acid (150,200, and 250 ppm),boric acid (30,60 and120 ppm),glycine amino - acid (20,40 and $80 \mathrm{ppm})$ and 5-salfosalicylic acid (100,200 and $300 \mathrm{ppm})$. Results indicated that all the used acids had positive effects on the keeping quality of cut Gladiolus spikes and using boric acid at level ranged between 30 to $120 \mathrm{ppm}$ to the vase solution led to increase the florets diameter, duration period and inhibit the growth of microorganisms in the vase solution. While using 5salfosalicylic acid at $\mathbf{1 0 0 - 2 0 0} \mathrm{ppm}$ gave a fast opening of the florets, increased the number of the opened florets, decreased the number of the non-opened florets per spike and increased the amount of the absorbed vase solution.
\end{abstract}

keyword: Gladiolus, Keeping quality.

\section{INTRODUCTION}

Gladiolus (Gladiolus grandiflorus L.) is an important bulbous ornamental crop among the elite cut flowers due to their different shapes and hues and excellent vase life (Bose et al.2003). It is valued for its wide range of flower colours and large number of florets per spike, and popular as cut flower in the domestic and international market. It is one of the four famous cut flowers in the world (Bai et al. 2009).

Vase-life is a yardstick for the longevity of cut flowers and is an important target for improving flower characteristics, whether by chemical treatment or plant breeding (Yamada et al. 2003).

Short postharvest vase life is one of the most important problems on the cut flowers. The maintenance of vase life is an important quality attribute in these economically significant cut flowers. A suitable method for vase life extension, which easy to use, natural, safe and inexpensive compounds is always crucial in this respect for large-scale applications.

\footnotetext{
${ }^{1}$ Fac.Agric. Alex.Uni. Depart. Of Flori.Ornam.Hort.and

Landscape Gardening

${ }^{2}$ Plant Pathology.

Received September 5, 2017, Accepted September 28, 2017
}

Vase life of cut flowers is mainly affected by two main factors, namely ethylene which accelerates the senescence of many flowers and microorganisms which cause vascular blockage and thus reduce the amount of water uptake, consequently the vase life of cut flowers could be reduced (Zencirkiran, 2010).

The water balance is also a major factor determining the quality and longevity of cut flowers. It is influenced by water uptake and transpiration and balance between two mentioned processes (Da Silva, 2003).

Ascorbic acid $\left(\mathrm{C}_{6} \mathrm{H}_{8} \mathrm{O}_{6}\right.$ "vitamin $\left.\mathrm{C}^{\prime \prime}\right)$ plays a role in electron transport system (El-Kobisy et al. 2005). Ascorbic acid also has been associated with several types of biological activities in plants such as in enzyme co-factors, antioxidant, and as a donor / acceptor in electron transport at the plasma membrane or in the chloroplast (Conklin, 2001).

Boric acid $\left(\mathrm{B}(\mathrm{OH})_{3}\right.$ or $\left.\mathrm{H}_{3} \mathrm{BO}_{3}\right)$ is another compound which delays senescence of some flowers such as carnation (Serrano et al.2001) and it inhibits ethylene production through reducing ACC synthase and ACC oxidase activities.

Glycine $\left(\mathrm{C}_{2} \mathrm{H}_{5} \mathrm{NO}_{2}\right)$ is the most common amino acid used in plant uptake studies and is thought to be particularly important as a nitrogen source for plants because of its low-molecular weight, low carbon-tonitrogen ratio and it inhibits the apparent photorespiration done by $\mathrm{C}_{3}$ (Zeiger, 2010). It stimulates the synthesis of chlorophyll and it activates the vegetative growth and it has a role in the process of photosynthesis and handling stressful situations that occur after the flowers picked.

5-sulfosalicylic acid $\left(\mathrm{C}_{7} \mathrm{H}_{6} \mathrm{O}_{6} \mathrm{~S}\right)$ is the salicylic acid (SA)-driven compound with sulfur group which may act more effective than SA because of its probable antimicrobial effect. Salicylic acid is an endogenous growth regulator of phenolic nature, which participates in the regulation of physiological processes in plants. SA can prevent ACC-oxidase and extend the vase life of cut flowers by decreasing reactive oxygen species (ROS) and ethylene (Zamani et al. 2011).

Therefore, the present work aimed to study the effects of various concentrations of ascorbic acid, boric acid, glycine amino-acid and 5-sulfosalicylic acid on the vase life and the growth of the microorganisms in the 
vase solution of gladiolus cut flowers at showing color stage under laboratory conditions.

\section{MATERIALS AND METHODS}

The present study included three experiments and they were conducted during two successive seasons of 2015 and 2016 at two different locations of Department of Floriculture ,Ornamental Horticulture and Garden Design Faculty of Agriculture University of Alexandria at Shatby and Behira governorate (Abo-El-Matameer city) under room conditions to investigate the effects of different concentrations of ascorbic acid (150,200 and $250)$, boric acid (30,60 and 120), glycine acid (20,40 and 80) and 5-sulfosalicylic acid (100,200 and 300) on the vase life, the growth of microorganisms in the vase solution and some chemical analysis of cut gladiolus spikes.

The used cut flower was Gladiolus grandiflorus cv. "White Prosperity" for its popularity in Egypt flowertrade. The flowers were obtained from a commercial nursery for flowers and ornamental plants in the outskirts of Cairo city.

The spikes were harvested early in the morning at showing color stage of the three basal florets, then they were quickly brought to the laboratory on $2 / 4 / 2015$, $11 / 2 / 2016$ and $25 / 2 / 2016$ for the first, second and third experiment, respectively. All spike stems were trimmed to have an average spike length of $85 \mathrm{~cm}$., 3-4 leaves and about 15 flower buds/spike.

Clean glass bottles were used as containers for the solution. Tap water was used in the preparation the holding solution and this solution was not changed or substituted until the end of the experiment. The volume of the holding solution was $780 \mathrm{ml}$ for each bottle. Control treatment contained $780 \mathrm{ml}$ tap water $+4 \%$ sucrose (Ezhilmathi et al. 2007) while the other treatments contained $780 \mathrm{ml}$ tap water $+4 \%$ sucrose + specific chemical and its concentration.

Mean temperature was $19^{\mathrm{oc}}\left( \pm 2^{\mathrm{oc}}\right)$ for the first experiment, $18^{\mathrm{oc}}\left( \pm 2^{\mathrm{oc}}\right)$ for the second experiment and it was $20^{\circ \mathrm{c}}\left( \pm 2^{\mathrm{oc}}\right)$ for the third experiment. While the averages of the relative humidity were $74 \%$ during the first experiment, $80 \%$ during the second experiment and $72 \%$ during the third experiments. The average of the light intensity for the three experiments was 733 lux.

At the end of the experiment, isolation trials from the vase- solutions of the different treatments were made by thoroughly shaking the solution of each treatment. One $\mathrm{ml}$ of each treatment was isolated on the surface of potato dextrose agar medium (PDA) by using sterilized one $\mathrm{ml}$ pipette. The inoculated plates were kept at room temperature $\left(22^{\mathrm{oc}} \pm 2^{\mathrm{oc}}\right)$. Each treatment was replicated three times. Examination of the inoculated petri-dishes was done every three days for a period of 15 days to know the developing microorganisms. The developed microorganisms were purified by using single spore isolation technique (Hildebrand, 1938) and they were identified to the generic level.

Data collected were floret full opening period (day), percentage of the opened florets per spike, number of the opened florets/spike, number of the non-opened florets /spike, floret diameter $(\mathrm{cm})$, floret duration period (day), inflorescence duration (vase-life) (day), florets dry weight $(\mathrm{g})$, total chlorophyll content (SPAD units) at the end of the experiment, total carbohydrates content $(\%)$, protein content $(\%)$, amount of absorbed vase solution per spike ( $\mathrm{ml} /$ day) and colony number of the isolated microorganisms.

The experimental layout was designed to provide randomized complete blocks design (RCBD) containing three replicates, each replicate contained 13 different treatments, and three inflorescences were used as a plot for each treatment in each replicate. The means of the individual factors were compared by L.S.D test at $5 \%$ level of probability (Steel and Torrie,1980).

\section{RERSULTS AND DISCUSSION}

\section{Floret full opening period (day):}

Generally, means of data of the three experiments presented in Table 1 indicated that using boric acid at 30 ppm gave the longest period required for florets to reach their full opening stage, compared with the other treatments, while using 5-sulphosalicylic acid at 200 ppm gave the shortest period which required for florets to reach their full opening stage, compared with the other treatments.

These results were probably due to the role of using boric acid at a specific concentration in plant. Using boric acid at a proper concentration probably led to delay the florets senescence through a strong inhibition of ethylene production (Serrano et al.2001), beside it activates photosynthesis process (Dale and Lukaszewski, 1998), consequently the florets development rate required a longer period. While 5sulfosalicylic acid has a crucial role in the regulation of physiological and bio-chemical processes during the entire life span of the plants and plays key roles in regulation their growth and productivity (Arbeg, 1981). Besides it modulates the synthesis and /or signaling of their hormones such as jasmonic acid, ethylene, and auxin (Raskin, 1992). All these factors probably led to accelerate the rate of the florets development, consequently, the required period for florets to reach their full opening stage could be reduced.

Similar trend of results was reported by Gargi and Devi (2005) and Parmer et al. (2002) on Gladiolus. 


\section{Percentage of the opened florets per spike:}

Data presented in Table 1 showed that all the used four acids with their concentrations gave significant increases in the percentage of the fully opened florets / spike, compared with the control treatment. Besides, using 5-sulfosalicylic acid at $200 \mathrm{ppm}$ gave the maximum percentage of the fully opened florets per inflorescence, compared with the other treatments, which led to increase the percentage of the fully opened florets with $28.02 \%$ over the control treatment (means of the three experiments).

These results may be probably due to the effect of adding 5-sulfosalicylic acid at a suitable concentration to the holding solution on enhancing the level of photosynthetic pigments, photosynthetic rate and modification the actively of some of the important enzymes as well (Yusuf et al.2013). Consequently, the production and accumulation of the bio-synthesis materials would be increased in the cut gladiolus spike, thus more florets could be developed and opened on the spike.

Similar trend of results was reported by Ezilmathi et al. (2007) on Gladiolus flowers, Rasul et al. (2011) on Gladiolus flowers and Nasibi et al., (2014) on tuberose.

\section{Number of the opened florets per spike:}

Generally, data of means of the three experiments presented in Table 1 showed that all the used materials led to increase the number of the fully opened florets per inflorescence of cut gladiolus spikes, compared with the control treatment. Besides, adding 5-sulfosalicylic acid at $200 \mathrm{ppm}$ to the holding solution gave the maximum number of the fully opened florets per inflorescence, compared with the control treatment, which led to increase the number of the fully opened florets with $15.69 \%$ over the control treatment.

These results may be probably due to that using 5sulfosalicylic acid at a suitable concentration in vase solution led to decrease the respiration rate (Ezhilmathi et al. 2007), delay senescence (Mackay et al. 2000), activate photosynthesis rate (Senaratna et al. 2000) and increase the vase solution uptake (Alaey et al. 2011). All these attributes led to increase the cumulative synthesis materials in the cut gladiolus spikes, consequently the number of the fully opened florets per inflorescence could be increased.

Similar trend of results was reported by Rao and Ram (1982) on Gladiolus sp. and EL-Mokadem (1991) on bird of paradise.

\section{Number of the non-opened florets per spike:}

Generally, data of means of the three experiments presented in Table 2 indicated that all the used acids led to decrease the number of the non-opened florets per gladiolus cut spike, compared with the control treatment. Also, adding 5-sulfosalicylic acid at $200 \mathrm{ppm}$ to the vase solution gave the minimum number of the non-opened florets per inflorescence, compared with the other treatments. The previous treatment led to decrease the number of non-opened florets per cut gladiolus spike with $55.85 \%$ under the control treatments.

These results were probably due to that using 5sulfosalicylic acid at suitable concentration in the vase solution led to activate photosynthesis rate (Senaratna et al., 2000), increase the vase solution uptake (Alaey et al., 2011). All these factors led to increase the cumulative synthesis materials in the cut gladiolus spikes, consequently most of the inflorescence florets could be opened, then the number of non-opened florets per spike would be decreased.

Similar trend of results was reported by Khattab et al. (1988) on Gladiolus sp.

\section{Florets diameter $(\mathrm{cm})$ :}

Data of means of the three experiments presented in Table 2 showed that using boric acid at $60 \mathrm{ppm}$ gave the biggest florets diameter of gladiolus plant, compared with the other treatments. The aforementioned treatments led to increase the florets diameter with $28.32 \%$ over the control treatment.

These results may be probably due to the role of boric acid at a proper concentration in plants. Boric acid increases chlorophyll content in the leaves (Raffeii and Pakkish, 2014), delay the senescence of flowers (Serrano et al.2001) and it can act in regulation of metabolism processes such as protein synthesis, transport of sugar and carbohydrate metabolism (Abd Elmotty and Fawzy,2005), accordingly, the net assimilation rate in gladiolus cut spikes would be increased, thus the flower quality could be improved.

Similar trend of results was reported by Mohammadi et al. (2014) on Gladiolus and Asgari and Moghadam (2015) on gerbera flowers.

\section{Floret duration period (day):}

Generally, data on means of the three experiment presented in Table 2 indicated that all the used materials led to increase the period of floret duration, compared with the control treatment. Besides, adding boric acid at $120 \mathrm{ppm}$ to the vase solution gave the maximum period of floret duration of cut gladiolus spike, compared with the other treatments. The previous treatment led to extend the floret duration period with $65.49 \%$ over the control treatment. These results may be due to that adding a suitable concentration of boric acid led to delay floret senescence and inhibit of ethylene production through reducing ACC-synthase and ACC-oxidase activities in cut flowers, consequently the period of floret duration could be increased. 


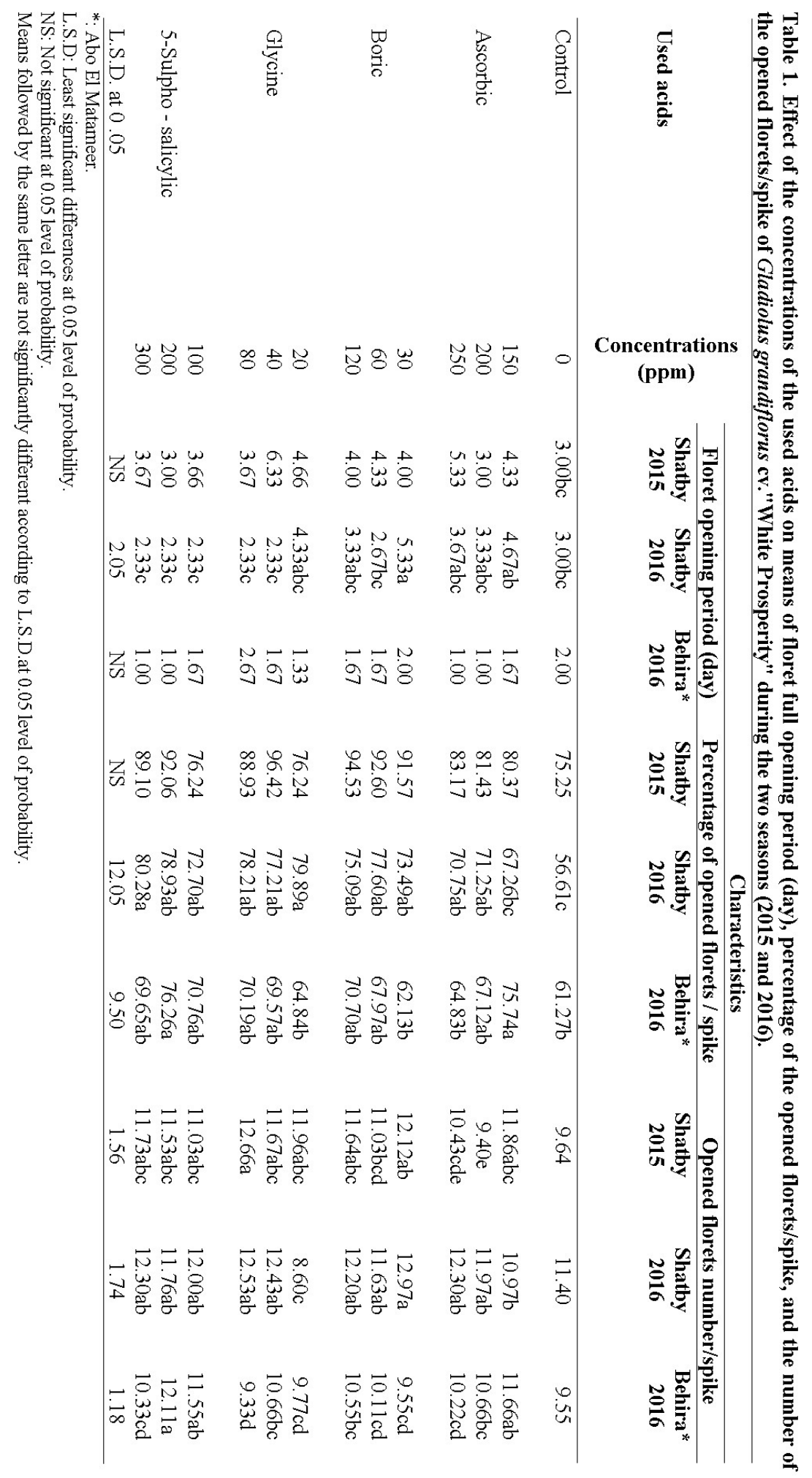




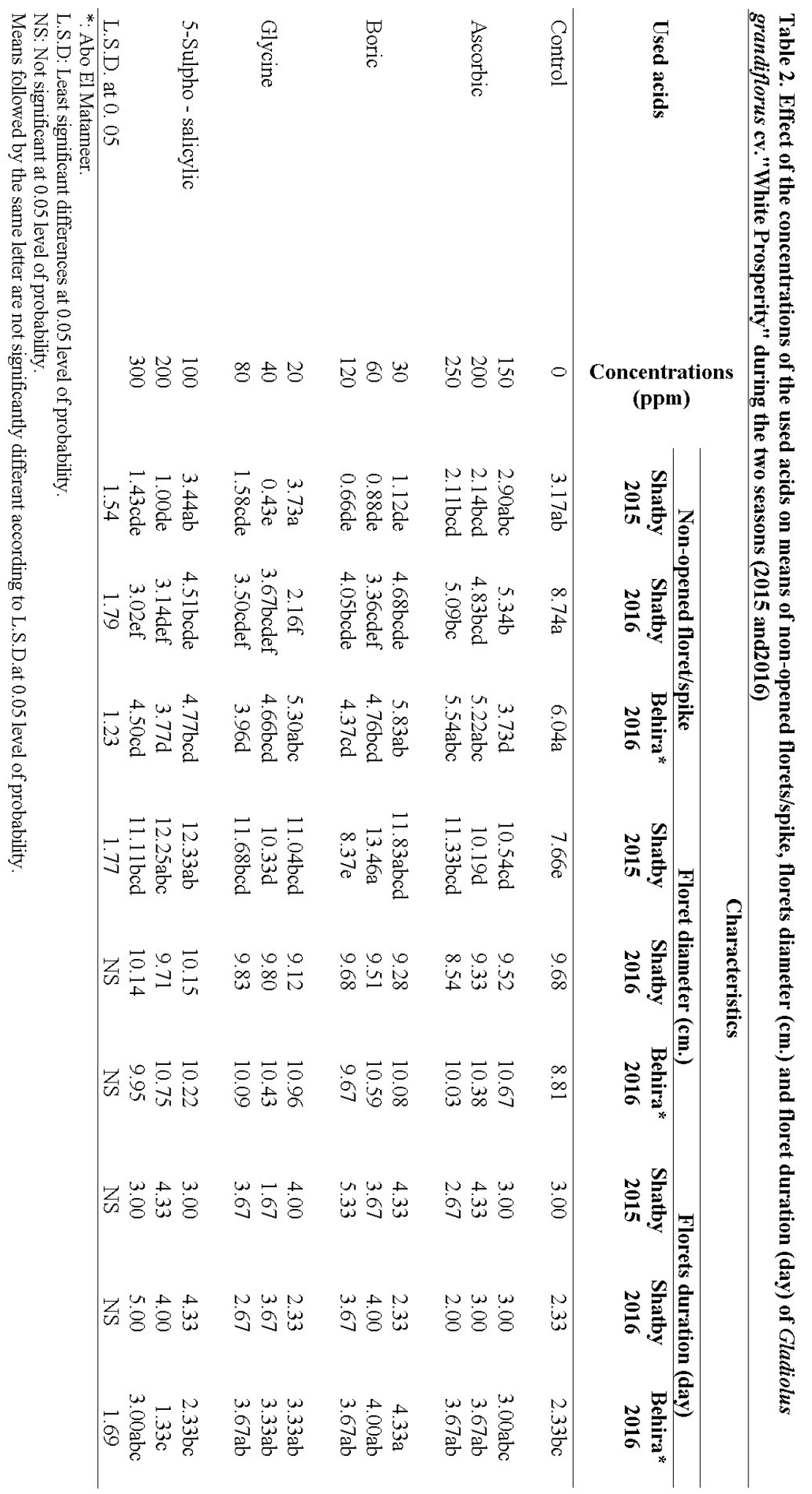


Similar trend of results was reported by Gargi and Devi (2005) on Gladiolus and tuberose and Hajizadeh and Alilooo (2014) on tuberose plants.

\section{Inflorescence duration (vase-life) (day):}

Generally, data on means of the three experiments presented in Table 3 showed that all the used materials led to extend the inflorescence duration of gladiolus cut spikes, compared with control treatment. Also, ascorbic acid treatments gave the longest vase life period of gladiolus cut spike. Besides, adding ascorbic acid at 150 $\mathrm{ppm}$ to the holding solution gave the maximum period of inflorescence duration, compared with the control treatment (means of the three experiments). The previous treatment led to increase the inflorescence vase life with $15.88 \%$ over the control treatment.

These results were probably due to the role of ascorbic acid at a suitable concentration which serves as an important co-factor in the biosynthesis of many plant hormones, including ethylene, gibberellic acid and abscisic acid (Barth et al.2006). Besides, ascorbic acid contributes to the detoxification of reactive oxygen species (Conklin and Barth, 2004). This will have profound effects on the regulation of development process including flower senescence, consequently, the period of inflorescence duration could be increased.

Similar trend of results was found by Liao et al. (2012) on Lilium plants, Ahmad and Dole (2014) on Zinnia plants and Sellam et al. (2016) on sweet sultan flowers.

\section{Florets dry weight (g):}

Generally, data on means of the three experiments presented in Table 3 on floret dry weight per cut spike showed that glycine treatments gave the highest effect on the dry weight of the florets, compared with the other materials. Also, adding glycine at $40 \mathrm{ppm}$ to the vase solution of gladiolus cut spike gave the heaviest florets dry weight, compared with the other treatments. The previous treatment led to increase the dry weight of the florets with $47.58 \%$ over the control treatment (as a mean of the three experiments).

These results may be related to the effect of glycine at a suitable concentration, which led to inhibit the photorespiration (Zeiger, 2010), stimulate the synthesis of the chlorophyll and activate the vegetative growth and photosynthesis process (Zaina et al.1995), consequently, the flower size could be increased and its dry weight would be too increased.

Similar trend of results was obtained by ElMokadem (1991) on Strelitzia reginae and Gargi and Devi (2005) on Gladiolus and tuberose plants.

\section{Total chlorophyll content (SPAD units):}

Generally, data presented in Table 3 indicated that there were reductions (decomposition) in the values of the total chlorophyll content of the cut gladiolus spike leaves at the end of the experiment, compared with the mean of values of chlorophyll content in the leaves of cut spike at the beginning of the experiment which was 60.51 SPAD units. These reductions were probably due to the normal decompositions of the leaf pigments after cutting the spikes.

Besides, adding glycine at $20 \mathrm{ppm}$ to the vase solution gave the minimum reduction of total chlorophyll content in the leaves of gladiolus cut spikes (as a mean of the three experiments), compared with the other treatments.

These results may be probably attributed to the direct role of glycine in the biosynthesis of the green pigments, which considers as a source for nitrogen and carbon as structural components of chlorophyll formation, hence using glycine at a proper concentration led to activate chlorophyll synthesis and protect its decomposition, consequently its content in the leaves of cut gladiolus spike could be maintained.

Similar trend of results was reported by Kazemi et al. (2012) on lisianthus and Kazemi and Ameri (2012) on carnation .

\section{Total carbohydrates content (\%):}

Generally, data of means of the three experiments presented in Table 4 indicated that using boric acid at 30 ppm gave the highest value of the total carbohydrates content in the leaves of gladiolus cut spike, compared with the other treatments, which led to increase the leaf content of carbohydrate with $42.76 \%$ over the control treatment (as a mean of the three experiments).

These results may be probably due to the role of adding boric acid at a suitable concentration in delaying leaf senescence through a strongly inhibition of the climacteric ethylene production (Serrano et al.2001), besides it increases vase solution uptake (Al-Attrakchii and Mahdawe, 2015) and activates the photosynthesis process (Dale and Lukaszewski, 1998), consequently the assimilated materials could be increased and the percentage of total carbohydrates in the leaves of cut gladiolus spikes would be increased.

This finding was similar to those found by ElMokadem (1991) on Strelitzia reginae and Hajizadeh and Aliloo (2014) on tuberose. 


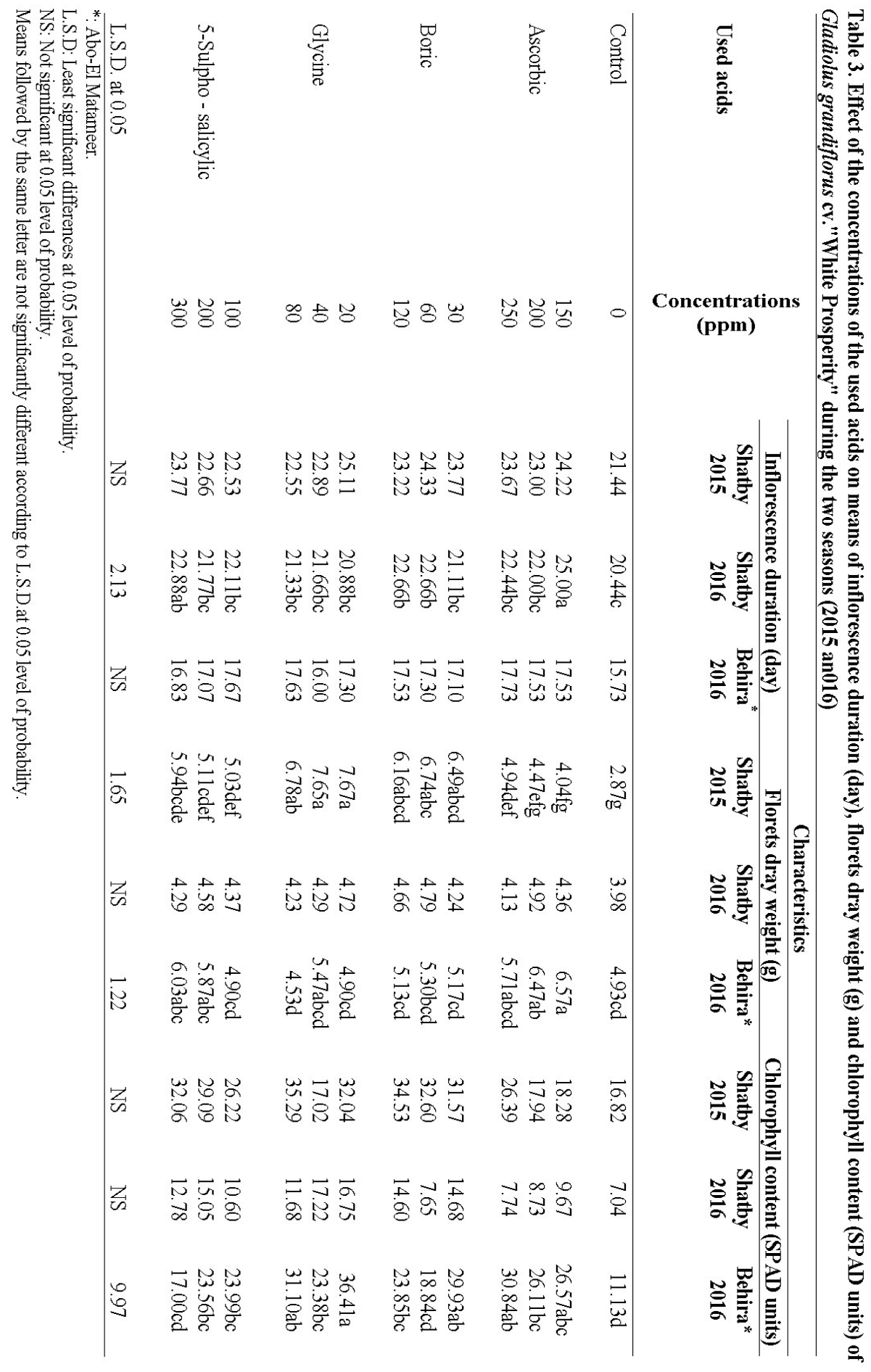




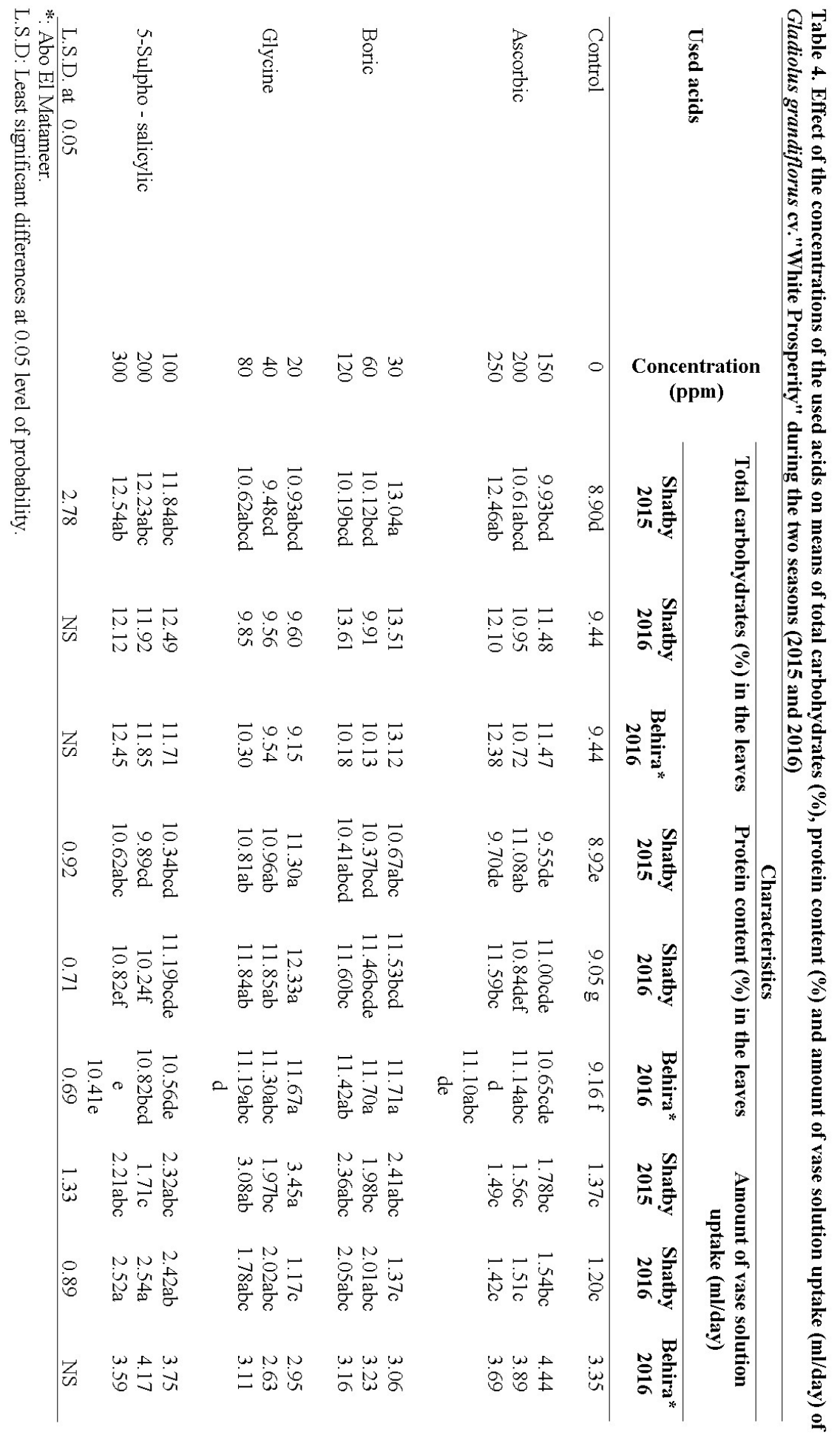




\section{Protein content (\%):}

Generally, data of the three experiments presented in Table 4 indicated that almost all the used acids with their concentrations gave significant increases of the nitrogen content of gladioli cut spike leaves, compared with the control treatment. Besides, using glycine acid at $20 \mathrm{ppm}$ gave the highest value of nitrogen content in the gladioli cut spike leaves, compared with the other treatments. The aforementioned treatment led to increase the nitrogen content in gladioli leaves with $30.20 \%$ over the control treatments (as a means of the three experiments).

These results were probably due to the role of glycine in plants, which it considered the building block of protein and chlorophyll and it serves as parts of coenzymes or as precursor of certain plant hormones and improves photosynthesis (Amin et al.2011), consequently the nitrogen content in the leaves of the cut gladiolus spike could be increased.

Similar trend of results was found by Kazemi and Ameri (2012) on carnation and Abri et al. (2013) on rose.

\section{Amount of the absorbed vase-solution(ml/day/spike):}

Generally, data on the means of the three experiments presented in Table 4 indicated that all the used materials gave increases in the amount of the absorbed vase solution by the cut gladiolus spikes, compared with the control treatment. Besides, adding 5sulfosalicylic acid with any concentration to the vase solution led to increase the amount of the absorbed vase solution, compared with the other treatments. Also, adding 5-sulfosalicylic acid at $100 \mathrm{ppm}$ to the vase solution gave the maximum amount of the absorbed vase solution, compared with the other treatments. The previous treatment led to increase the amount of the absorbed vase solution with $43.65 \%$ over the control treatment (as a mean of the three experiments, Table 4).

These results may be probably due to the role of 5sulfosalicylic acid at a proper concentration in plants. 5sulfosalicylic acid protects chlorophyll (Peng et al.2007), and protein degradation (Soobedar et al.2015), delays the senescence of the tepals of cut gladiolus flowers (Hatamzadeh et al.2012), enhances the relative water content of leaves (Hassan and Ali, 2014), prolongs membrane stability. All these factors probably led to increase the efficiency of the cut gladiolus spikes to absorb a large amount of the vase solution.

Similar trend of results was reported by Dantuluri et al. (2008) on Gladiolus, Sardoei et al. (2013) on Narcissus and Puneet and Mukherjee (2015) on pot marigold.

\section{Colony number per Petri dish:}

Generally, results of the isolation of the microorganisms from the vase solution on potato dextrose medium showed that there were only two distinct groups of microorganisms i.e. Penicillium $s p$. and yeasts.

With respect to the data of the three experiments presented in Table 5 it is clear that using boric acid gave the lowest colonies number of the two isolated microorganisms, compared with the other treatments.

Besides, adding boric acid at $120 \mathrm{ppm}$ led to a large inhibition of the microbial growth in the vase solution, compared with the other treatments. The previous treatment led to decrease the colonies number of the two isolated microorganisms with $95.46 \%$, compared to the control treatments, (as a mean of the three experiments).

These results were probably due to the role of boric acid at a suitable concentration in inhibition of the microbial growth of Penicillium $s p$. and yeasts as reported by Davood et al. (2014).

Similar trend of results was reported by El-Mokadem (1991) on cut bird of paradise flowers, Hajizadeh and Aliloo (2014) on tuberose, Al-Attrakchii and Mahdawe (2015) on carnation and Azizi et al. (2015) on lisianthus.

\section{REFERENCES}

Abd-Elmotty, Z.E., and M. F. Fawzy. 2005. Response of Zebda and Langora mango trees to some bio- fertilization treatments. J. Agric. Sci. Mansoura Univ.30(6). 33313341 .

Abri, F., M. Ghasemnezhad., R. Hasansajedi and D. Bakhshi.2013. Effect of ascorbic acid on vase life and petal senescence in cut rose flowers (Rosa hybrida) cv. Royal Class. Am-Euras. J. Agric.\&Environ. Sci.,13(1): 38-43.

Ahmad, I and J. M. Dole. 2014. Homemade floral preservatives affect postharvest performance of selected specialty cut flowers. Hort Technology.24(3):384-393.

Alaey, M., M. Babalar., R. Naderi and M. Kafi. 2011. Effect of pre- and postharvest salicylic acid treatment on physiochemical attributes in relation to vase-life of rose cut flowers. Postharvest Biology and Technology. 61(1):9194.

Al-Attrakchii, A. O., and M. M. Al-Mahdawe. 2015. Effect of boric acid on flowers longevity of two cultivars of Dianthus caryophyllus L. Diyala Journal of Agricultural Sciences. 7(1):102-110.

Amin, A. A., A. E. Fatma, M. Gharib, El-Awadi and S. M. Rashad. 2011. Physiological response of onion plants to foliar application of putrescine and glutamine, Scientia Horticulture, Volume 129: 353-360.

Arbeg, B. 1981. Plant growth regulators monosubstituted benzoic acid. Swed. Agric. Res. 11,93-105. 
Asgari, M., and A. L. Moghadam. 2015. Comparison of different salicylic acid application ways as a preservative on postharvest life of gerbera cut flowers. Agricultural Communications. 3(4): 1-8.

Azizi., S., O. Rasoul and B. Kaviani. 2015. Effect of ascorbic acid on post -harvest vase life of cut lisianthus (Eustoma grandiflorum L.) flowers. ARPN. J. Agri. Biol. Sci. 10(11) :417-420.

Bai, J. G., P.L. Xu., C. S. Zong and C. Y. Yang. 2009. Effects of exogenous calcium on some postharvest characteristics of cut gladiolus.Agric. Sci. China, 8 293303.

Barth. C., M. D. Tullio and P. L.Conklin. 2006. The role of the ascorbic acid in the control of flowering time and the onsets of senescence. Exp. Bot 57: 1657-1665.

Bose, T. K., L. P. Yadav., P. Pal., V. A. Parthasarathy and P. Das. 2003.Commercial flowers, Vol, II. Naya Udyog, Kolkata, India.

Conklin, R. 2001. Advances in the role of biosynthesis of ascorbic acid in plant cell environment, 24: 383-394.

Conklin, P. L., and C. Barth. 2004. Ascorbic acid, a familiar small molecule intertwined in the response of plants to ozone, pathogens, and the onset of senescence. Plant, cell and Environment 27: 959-971.

Dale, G. B., and K. M. Lukaszeweski. 1998. Boron in Plants structure and function. Ann. Rev. Plant Physiol. Plant Mol. Biol. 49:481-500.

Dantuluri, V. S. R., R. L. Misra and V. P. Singh. 2008. Effect of polyamines on post-harvest life of gladiolus spikes. Journal of Ornamental Horticulture. 11(1):66-68.

Da Silva, J. T. 2003. The cut flower: postharvest considerations. Biol. Sci.,3: 406-42.

Davood, H., M. H. Liavali., B. Kaviani., M. Mousavi., S Keyghobadi and S. Zahiri. 2014. Effect of nano silver and boric acid on extending the vase life of cu rose (Rosa hybrida L.). Journal of Environmental Biology. 35(5):833-838.

El-Kobisy, D. S., K. A. Kady., R.A. Hedani and R.A. Agamy. 2005. Response of pea plant (Pisum sativum) to treatment with ascorbic acid. Egypt. J. Apple. Sci. 20: 36-50.

El- Mokadem, H.S. 1991. Effect of some chemicals on the keeping quality of cut flowers of Strelitzia reginae banks.M.Sc. Thesis Alex University.

Ezhilmathi, K., V. P. Singh., A. Arora and R. K. Sairam. 2007.Effect of 5-sulfosalicylic acid on antioxidant activity in relation to vase life of Gladiolus cut flowers. Plant Growth Regulation. 51(2):99-108.

Gargi, S and J. Devi. 2005. Effect of different holding solutions on post-harvest quality of cut tuberose and gladiolus spikes. Mysore Journal of Agricultural Sciences. 39(4):447-451.

Hajizadeh, H. S. and A. A. Aliloo. 2014. Postharvest quality studies in tuberose (Polianthes tuberosa cv. Peril) cut flower as affected by vase preservative solutions. International Journal of Agriculture Innovations and Research. 2(6):895-899.

Hassan, F. A. S., and E. F. Ali. 2014. Protective effects of 1methylcyclopropene and salicylic acid on senescence regulation of gladiolus cut spikes. Scientia Horticulture. 179:146-152.
Hatamzadeh, A, M., M. Hatami and M. Ghasemnezhad. 2012.Efficiency of salicylic acid delay petal senescence and extended quality of cut spikes of Gladiolu grandiflorus cv 'Wing's Sensation'. African Journal of Agricultural Research. 7(4):540-545.

Hildebrand, E. M. 1938. Techniques for the isolation of single microorganisms. Bot. Rev., 4:628-658.

Kazemi, M., and A. Ameri. 2012. Extending the vase life of carnation with different preservatives. International Journal of Botany. 8(1):50-53.

Kazemi, M., M. Asadi and S. Aghdasi. 2012. Postharvest life of cut lisianthus flowers as affected by silicon, malic acid and acetylsalicylic acid. Research Journal of Soil Biology. 4(1):15-20.

Khattab, M., T. El-Kiey and M. Haikal. 1988. Influence of maleic hydrazide and sucrose on the keeping quality of cut Gladiolus spikes. Alex. J. Agric. Res. 33(2): 113-125.

Liao, W. B., Z. M. Ling., H. G. Bao and Y. J. Hua. 2012. Hydrogen peroxide in the vase solution increases vase life and keeping quality of cut Oriental x Trumpet hybrid lily 'Manissa'. Scientia Horticulture. 139:32-38.

Mackay, W. A., N. Sankhla., D. Sankhla and T. D. Davis. 2000. Postharvest performance of Lupinus havardii Wats., a new cut flower crop. Lupine, an ancient crop for the new millennium: Proceedings of the $9^{\text {th }}$ International lupine Conference, Klink/Muritz, Germany. :330-332.

Mohammadi, G. A., A. S. Sardoei and M. Shahdadneghad. 2014. Improvement of the vase life of cut gladiolus flowers by salicylic acid and Putrescine. International Journal of Advanced Biological and Biomedical Research. 2(2):417-426.

Nasibi, F., H. Farahmand., A. Kamyab and S. Alipour. 2014. Effects of arginine, cysteine and 5-sulfosalicylic acid on of vase life of tuberose cut flowers. Agricultural Communications. 2(2):35-41.

Parmar, A. M., D. B. Mahitaljamwal., D. B. Singh and R. L. Misra. 2002. Postharvest life of cut gladiolus spikes. Journal of Ornamental Horticulture (New Series). 5(1):87-88.

Peng, X.L., R. J. Ping and Z. Y. Long. 2007. Effect of exogenous salicylic acid on vase life of cut flowers of Prato lily and related physiological influence. [Chinese]. Acta Horticulture Sinica. 34(1):189-192.

Puneet, K and D. Mukherjee. 2015. L-serine and spermine delay petal senescence in cut flowers of Calendula officinalis L. Lifesciences Leaflet. 69:112-124.

Raffeii, S., and Z. Pakkish.2014. Effect of boric acid spray on growth and development of "Camarosa" strawberry (Fragaria $x$ ananassa Duck.) International journal of advanced Biological and Biomedical Research. Vol.2, Issue 4,2014:1060-1063.

Rao, I.V., and H. M. Ram. 1982. Specificity of Gibberellin and Sucrose-promoted flower bud growth in Gladiolus. Ann Bot 50(4): 473:479.

Raskin, I. 1992. Salicylate, a new plant hormone. Plant Physiol., 99, 799-803.

Rasul, J. M., A. Hassani., A. Abdollahi and S. Hanafi. 2011. Improvement of the vase life of cut gladiolus flowers by essential oils, salicylic acid and silver thiosulfate. J. Medic. Plants Research. 5(20): 5039-5043. 
Sardoei, A. S., A. M. Gholam and R. Parviz. 2013. Interaction effect of salicylic acid and putrescine on vase life of cut narcissus flowers. Intr. J. Adv. Biol Biome Res $.1(12): 1569-1576$.

Sellam, P., B. Singh., P. Rai and J. Majumder.2016. Potential of field grown sweet sultan (Centaurea moschata) as cut flower based on vase life. Indian Journal of agricultural sciences. 86(4):465-470.

Senaratna, T., D. Touchell., E. Bunn and K. Dixon. 2000. Acetyl salicylic acid (Aspirin) and salicylic acid induce multiple stress tolerance in bean and tomato plant. Plant Growth Regulation, 30, 157-161.

Serrano, M., A. Amoros., M.T. Pretel., M.C. MartinezMadred and F. Romojaro. 2001. Preservative solutions containing boric acid delay senescence of carnation flowers. Postharvest Biology and Technology 23: 133142.

Soobedar, Y., P. N. Kumar., A. Arora and R. Kumar.2015. Effect of protease inhibitors on physiological and biochemical changes influencing keeping quality in gladiolus. Indian Journal of Horticulture. 72(1):92-99.
Steel, R. G and J. M. Torrie.1980. Principles and Procedures of Statistics $2^{\text {nd }}$ ed. Mc Graw-Hill Co. Inc., New York, U.S.A.

Yamada, T., Y. Takatsu., T. Manabe., M. Kasumi and W. Marubashi.2003. Suppressive effect of trehalose on apoptotic cell death leading to petal senescence in ethylene-insensitive flowers of gladiolus. Plant Science. 164(2):213-221.

Yusuf, M., H. Shamul, M. N., Alyemeni, F. Qazi and A. Aqil. 2013. Salicylic acid: physiological Roles in plants'. ISBN:974-94-007-6427-9 page 1:16.

Zaina, M., M. Yousif and A. El-Banna .1995. Agricultural Biochemistry. Alex Univ. Egypt.

Zamani, S., M. Kazemi and M. Aran. 2011. Postharvest life of cut rose flowers as affected by salicylic acid and glutamine. World Applied Sciences Journal 12(9) :16211624.

Zeiger, T. 2010. Plant physiology $.5^{\text {th }}$ ed. Sinaure Associates.

Zencirkiran, M. 2010. Effect of 1-MCP (1-Methyl Cyclopropene) and STS (Silver thiosulphate) on the Vase Life of Cut Freesia Flowers. Sci. Res. Essay. 5 (17): 2409-2412.

$$
\begin{aligned}
& \text { الملخص العربي } \\
& \text { تـأثثر بعض المواد الكيماوية على مدة حياة أزهار الجلاديولاس المقطوفة } \\
& \text { محمود خطاب، محمد التركى، عبد الحميد طر ابية، هند راثد }
\end{aligned}
$$

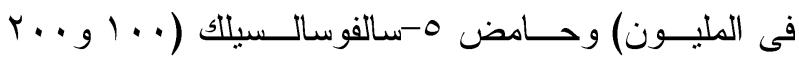

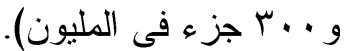

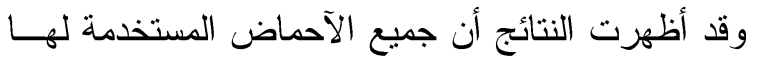

$$
\begin{aligned}
& \text { تأثبر موجب على جودة أزهار الجلاديولس المقطوفة. وأن } \\
& \text { إضافة حامض البوريك بتركيز يتر اوح من ·r إلـى •r } \\
& \text { جزء فى المليون يزيد من قطر الزهيرات ويطيل عمرهـــا }
\end{aligned}
$$

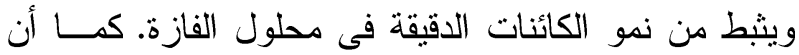

$$
\begin{aligned}
& \text { إستخدام حامض 0-سالفوسالسيلك بتركيز يتز اوح من م. .. }
\end{aligned}
$$

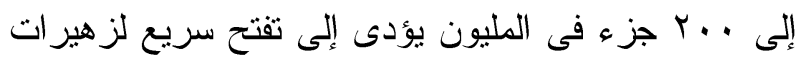

$$
\begin{aligned}
& \text { النورة ويزيد من عدد الزهيرات المتفتحة ويقلل مــن عـدد }
\end{aligned}
$$

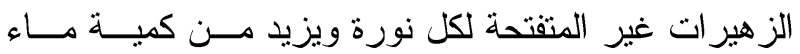

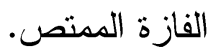

